\title{
Digital Communication: A New Challenge for Moral Discernment ${ }^{* *}$
}

Digital communication is based on the conversion of analogue information into digital information as well as the transmission and processing of digital information. This fundamentally changes the nature of human communication. The promised effects of the digitalization of communication are to save time and create more freedom of action. However, digital communication also leads to new dependencies and social control. This generates a new challenge for moral discernment.

Keywords: Digital Communication, Social Control, Moral Discernment, Alienation

\section{Digitale Kommunikation: Eine neue Herausforderung für moralisches Urteilsvermögen}

Digitale Kommunikation basiert auf der Umwandlung analoger Größen in digitale Informationen sowie der Übermittlung und Verarbeitung von digitalen Informationen. Dadurch ändert sich menschliche Kommunikation grundlegend. Verheißungen sind Zeiteinsparung oder mehr Handlungsfreiheit. Doch gehen diese Entwicklungen nicht nur mit neuen Freiheiten einher, sondern führen ebenso zu neuen Abhängigkeiten und sozialer Kontrolle. Dies stellt moralisches Urteilsvermögen vor eine neue Herausforderung.

Schlagwörter: Digitale Kommunikation, Soziale Kontrolle, Moralisches Urteilsvermögen, Entfremdung

\section{Introduction}

\subsection{What is the Problem?}

Social change has always been tied to technological change (cf. Hampton 2016: 104). Digitalization is an overarching technological change, which is discussed and analyzed within different disciplines. This article focuses on digital communication. Digital communication encompasses human-to-human, human-tomachine as well as machine-to-machine communication. This analysis concerns human-to-human communication in professional relationships.

* Elisa Maria Entschew, HHL Leipzig Graduate School of Management, Jahnallee 59, D-04109 Leipzig, Tel.: +49-(0)341-9851751, E-Mail: elisa.entschew@hhl.de, Fields of Research: Ethics of Digital Communication, Interaction Ethics, Leadership Ethics, Hyperinclusion.

Prof. Dr. Andreas Suchanek, HHL Leipzig Graduate School of Management, Jahnallee 59, D-04109 Leipzig, Tel.: +49-(0)341-9851871, E-Mail: andreas.suchanek@hhl.de, Fields of Research: Economic and Business Ethics, Corporate Responsibility, Trust and Value Management, Leadership Ethics.

** The manuscript was submitted on February 28th 2017 and accepted on September $1^{\text {st }}$ 2017 after double-blind review process. 
The conditions of human communication are changing. One of the changes is the rise of new social control (cf. section 3.2) resulting from acceleration of communication (cf. section 2.1), a changing desire for resonance ${ }^{1}$ (cf. section 2.1) and greater prevalence of indirect communication (cf. section 2.2). A challenging feature of social control is its subtlety: corporate members do not feel heteronomous control. They even feel like having great freedom, although they are complying much more with corporate standards (cf. O'Reilly 2008: 88). The term scorporate members includes managers as well as employees at non-managerial level (the latter will be referred to as semployeess) throughout the article.

Due to the changing conditions of digital communication between humans, moral discernment is faced with new challenges. The theoretical contribution of this article is to examine newly developing social control forces and their impact on moral discernment.

Digital communication promises more freedom (cf. Schmidt/Cohen 2014: 3, 7, $15 \mathrm{ff}$.). However, there are also unintended consequences of social control such as the prevalence of permanent availability or secret surveillance. ${ }^{2}$ The parallel development of freedom and control is inevitable and nothing novel, especially in professional relationships. Nevertheless, the subtlety of social control through digital communication (digital social control) ${ }^{3}$ makes it increasingly difficult to understand one's conditions of communication.

Crawford (2016: 142f.) suggests that the difficulty of understanding one's conditions of action and their causal relationships systematically increases in our complex (corporate) worlds with diverse interdependencies. The ability to understand one's dependencies is requisite for moral discernment. It will become clear that a new challenge for moral discernment stems from the weak digital literacy of corporate members.

The conceptualization of moral discernment reveals new difficulties in deriving the >right decisions $<$ Ethical considerations such as $>$ What is the right thing to do? thereby become presumably more complicated. The authors therefore claim that digital social control poses a new challenge to moral discernment.

Nonetheless, the difficulty of adequately understanding one's own environment is not a new challenge, per se. In earlier centuries, it was difficult to understand one's environment due to a lack of information. Nowadays, it is becoming more and more difficult to understand one's environment due to the subtlety (cf. Hamil-

1 Resonance describes the desire of humans to be recognized by and connected to others (cf. Rosa 2016: 24f., 198f., 281-298).

2 The authors do not intend to undermine new opportunities of digitalization. Nonetheless, they do aim to identify possible risks of digitalization that have the potential to undermine freedom. This is in accordance with the German Federal Minister of Labor, Andrea Nahles (2016: 107): she encourages analyzing foreseeable risks in the context of digital (work) environments in order to make use of the possible opportunities, while not undermining societal achievements such as social order or freedom.

3 The authors are mainly referring to digital social control, encompassing social controls enabled through digital communication, even if the term >digitak is not always explicitly used. 
ton et al. 2014; Mittelstadt et al. 2016) and overload of information (cf. Zuboff 1988: 348; Rosa 2014 [2005]: 116-122). A possible means of dealing with an increased amount of information is to be available permanently ${ }^{4}$ (cf. Hassler et al. 2016: 36; Menz 2017: 20f.).

Some companies have already reacted to such issues of digital communication. However, most of these regulations apply to the topic of availability and do not apply to management positions:

- BMW: Since 2014, a company agreement commits to define binding times of unavailability; it also regulates that corporate members are able to unbureaucratically record 'mobile work in their working time accounts (cf. Boewe/ Schulten 2014: 18). BMW's works council received the German award for workers' councils (Deutscher Betriebsrätepreis) for this innovative company agreement on smobile work (cf. Herrmann 2014).

- Evonik: Since 2013, availability is a central leadership topic and rules have been established for all 21,000 corporate members in Germany; appraisal meetings are used in order to individually agree on suitable scopes of availability (cf. Giersberg 2014).

- Daimler: Since 2013, if an employee has activated the auto-reply regarding unavailability, all incoming e-mails are deleted and need to be sent again by the sender (cf. Kaufmann 2014; Dörner 2014).

- Volkswagen: Since 2011, a company agreement regulates that 30 minutes after regular working hours, e-mails will not be forwarded until 30 minutes prior to the official start of the next day; this only counts for 3,500 employees with collective agreements and corporate mobile phones and it does not count for executives (cf. Kaufmann 2014).

- Continental AG: Employees can consult a guideline for advice about possible ways of interrupting permanent availability, such as setting up filters for calls and e-mails as well as transparently communicating these interruptions (cf. Hoffmann 2014a).

- Deutsche Telekom: Since 2010, employees can rely on a policy which commits managers to abstain from sending e-mails after working hours, employees are not obliged to react to e-mail requests after regular working hours (cf. Hoffmann 2014b; Hassler et al. 2016: 57). Additionally, managers are taught how to shape a conducive work environment in shealthy leadership training (cf. Hassler et al. 2016: 57).

These examples suggest that there is a need for unavailability. With reference to the Telekom example, there is also some indication on the development of specific

4 Permanent availability is understood as unregulated availability for professional interests, including outside of regular working hours (cf. Hassler et al. 2016). In addition, there is no clear specification on the reaction time if an employee is contacted (cf. Hassler/Rau 2016: 26). Strobel (2013: 18) identifies the following advantages of permanent availability: gains in flexibility and mobility, which is particularly relevant for parents; faster support from corporate members or identity and status enhancement. 
training for managers. A systematic overview of these and other examples is provided by the German Federal Ministry of Labour and Social Affairs (2015).

Other issues of digital communication refer to new possibilities of surveillance. The incidents of internal surveillance in companies are increasing (cf. MDR 2017). One such example is the ADAC (German automobile club) case, where corporate members systematically checked e-mail content of other corporate members (cf. Witte/Wendt 2013).

Another example is the usage of software called 'Keylogger', which enables every keyboard input of corporate members to be recorded. Based on upcoming cases, the Federal Labor Court passed a law that forbids the use of such software (cf. Bundesarbeitsgericht 2017). However, corporate members might face problems in understanding and trusting these newly developing conditions.

The authors derive two needs for action:

1. Integration of rules of unavailability (new regulations for corporate members ${ }^{5}$ )

2. Institutionalization of professional training of moral discernment in order to promote responsible business behavior in times of digital communication (new two-level-training for managers ${ }^{6}$ )

In regard to the first issue, practical and academic work is prevalent (cf. Pangert et al. 2017; Menz 2017; Hassler/Rau 2016; Hassler et al. 2016; Boewe/Schulten 2014; Derks et al. 2014; Strobel 2013; Derks et al. 2012). The second issue has not been discussed very prominently so far (an attempt, mainly focusing on the subtlety of algorithms ${ }^{7}$ can be found here [cf. Mittelstadt et al. 2016]). As such, the authors focus on this second issue (mainly focusing on the subtlety of social control via human-to-human communication).

Since both issues (1. and 2.) are closely related, the availability problem is part of the following analysis. Though not part of the theoretical contribution, it sheds some light on unintended consequences of social control.

Based on these considerations, the theoretical contribution of this article is firstly to reconstruct newly developing social control forces and their impact on moral discernment. From this standpoint, the authors develop a new theoretical category of digital alienation. The following research question guides the reader throughout the line of argument:

5 Since managers have overarching responsibilities, unavailability rules have to be adapted with regard to these responsibilities. However, in order to not lose track of the bigger picture, which is relevant for responsible decision-making, they also need >breathing room outside of their professional roles (cf. section 4.2).

6 Indeed, also employees at non-managerial level should be equipped with an adequate moral discernment in order to encourage responsible decision-making. However, due to the overarching scope of responsibilities as well as the role model function of managers, the authors derive the recommendation to institutionalize training for management positions (cf. 4.1).

7 It should be noted that algorithms play an integral role in every form of digital communication. This analysis, however, does not focus on the effects of algorithms. 
How does digital communication affect moral discernment?

The authors' main proposition is that digital communication challenges moral discernment in a new way. In particular, the following hypotheses are proposed throughout the analysis:

H1: Digital communication gives rise to new (digital) social control forces.

H2: Digital social control makes it harder for corporate members to understand conditions of communication.

H3: When a solid understanding of conditions of communication is lacking, strong moral discernment is impossible.

H4: If moral discernment is not trained within companies, a potential outcome is digital alienation.

The causal relationship of the hypotheses ${ }^{8}$ is illustrated in the figure below:

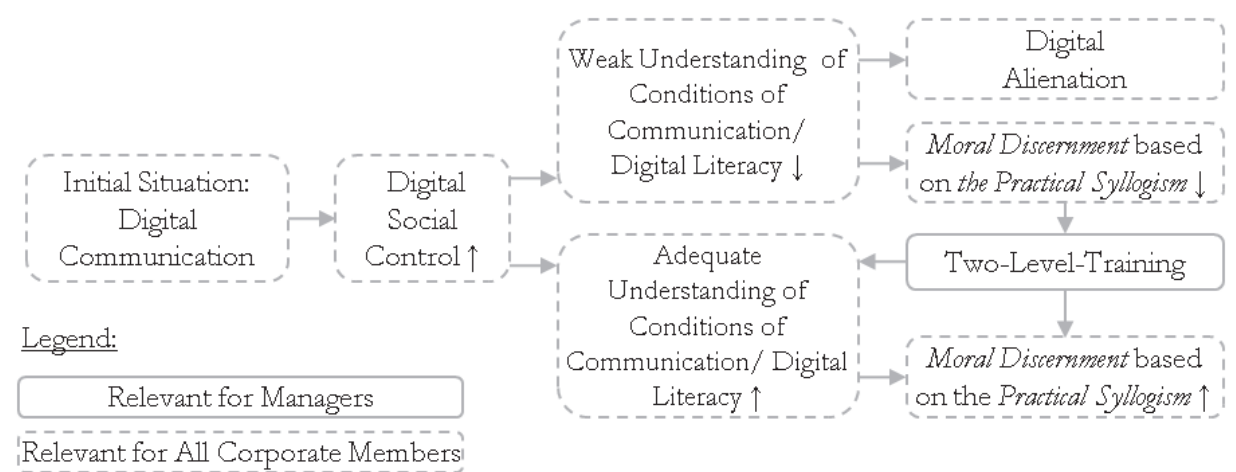

Figure 1: The Challenge for Moral Discernment Caused by Digital Communication (Source: Own illustration)

\subsection{Procedure and Basic Assumptions}

The analysis starts with an introduction of digital communication and social control in order to examine the changing conditions of human communication in professional relationships $\left(\mathrm{H}_{1}\right.$ and $\left.\mathrm{H}_{2}\right)$. It should be noted that digital communication leads to other changes as well, but only those changes that are relevant to the research question are presented in the chapter. The changes which are discussed relate to social controls resulting from acceleration, a changing desire for resonance and greater prevalence of indirect communication.

The next section is dedicated to developing a theoretical understanding of the concept of moral discernment. The competence in moral discernment is conceptualized via the heuristic of the practical syllogism (cf. Suchanek 2015: 42-46).

8 While the hypotheses are relevant for all corporate members, the recommendation of two-level-training is aimed at managers (two-level-training is addressed in section 4.1). 
On this basis, the changing difficulty of understanding one's conditions of communication through social control is related to the practical syllogism $\left(\mathrm{H}_{3}\right)$. Subsequently, the new category of digital alienation is derived $\left(\mathrm{H}_{4}\right)$. Finally, the outlook discusses recommendations for corresponding investments of companies.

The analysis is based on assumptions of interaction ethics (cf. ibid.). One relevant assumption is that ethics does not only refer to one person, but also to the rest of society, involving other humans and institutions. ${ }^{9}$ This assumption implies the embeddedness of a person within the social dimensions. Social embeddedness means that one's actions influence the conditions and actions of others. This assumption plays a significant role throughout the article.

The article mainly argues on the meso- (company) and micro-level (corporate members), although social control and norms are also elements of the macro-level (societal norms).

The authors cannot deny influences from macro-level as well. For example, digital communication has surely blurred the line between private and professional life.

Whilst the focus of this article squarely lies on professional relationships, it is not always feasible to achieve a clean separation from private relationships due to the described sblurring of the liner. Nonetheless, the theoretical contribution of this article addresses the organizational changes through digital communication (meso-level) and the resulting challenge for moral discernment (micro-level). Since these changes are based on the embeddedness of corporate members in their organization, the recommendations are derived on the meso-level. These are investments that companies can make in their members' power of moral discernment.

\section{Digital Communication and Social Control: What is Changing?}

\subsection{Acceleration and Resonance: The Path to Availability}

Digital communication refers to the culture of exchanging information enabled through the omnipresence of digital devices. Common promises are time savings and more freedom (cf. Schmidt/Cohen 2014: 3, 7, 15ff.). Via digital communication, corporate members have more freedom to communicate with each other everywhere, all the time and in various manners.

One basic changing condition in human communication is acceleration: more content is communicated in the same time period, or the same volume of content is communicated in less time. It means a quantitative growth per time unit (cf. Rosa 2016: 13, 673). As a result, the amount of communicated information increases.

In Germany, the amount of e-mails has increased from 32.3 billion in 2000 to 625.8 billion in 2016 (cf. United Internet 2017). It is expected that from 2017 to 2021 the amount of sent and received e-mails per day will further increase world-

9 Institutions comprise rules and laws, social norms, sanctioning mechanisms and other incentives. 
wide (cf. The Radicati Group 2016). ${ }^{10}$ These developments make accelerated communication apparent: the amount of communicated information increases per time unit ( $\frac{\text { exchanged information: } \mathrm{q}}{\text { time unit: } \mathrm{t}} \uparrow$ ).

For a better understanding of accelerated communication, a hypothetical example is helpful (cf. Rosa 2014 [2005]: 119f.): Acceleration enables that writing and sending an e-mail takes approximately only half of the time than a conventional letter would do. However, if we suppose that the amount of processed e-mails is roughly four times higher than the number of written letters $\left(\frac{q \times 4}{t \times \frac{1}{2}}=\frac{q}{t} \uparrow\right)$; the actual required time for communication has doubled. This increase of spent time for communication can be understood as a self-reinforcing mechanism: if an answer is available on the same day instead of within 14 days, an inherent, selfreinforcing impulse of accelerated communication is resulting. Obviously, while the purpose of faster communication aims at reducing time consumption for correspondence, paradoxically the spent time would increase. ${ }^{11}$ Often corporate members are not able to spend more time on communication due to other job commitments. Hence, they have to compensate for the increased amount of communicated information per time unit. As indicated earlier, a possible way of handling an increased amount of information is to be available permanently (cf. Hassler et al. 2016: 36; Menz 2017: 20f.).

Digital communication offers opportunities such as easy and fast communication. Also, the extent of freedom increases as one can decide when to contact somebody independent from time and space or other resources (cf. Hampton 2016: 111). However, as a lot of corporate members are able to receive and answer digital messages always and everywhere - especially since smartphones, tablets or smart watches developed into omnipresent digital devices - the described impulse of accelerated communication may develop. A pressure of being salways on< is established (cf. Menz 2017: 22).

This (partially unconscious) pressure may be based on the attempt to achieve resonance experiences: humans want to be recognized by and connected to others

10 Since there is no data on the increase of work-related e-mails, data on the development of all e-mails in Germany respectively worldwide is used as a proxy of the increase.

11 Certainly, there are other purposes such as an extended audience (cf. Baumanns et al. 2015) or free movement of information (cf. Schmidt/Cohen 2014). These are also accompanied with paradoxical challenges (cf. Böldicke/Erfurt Sandhu 2017). While an extended audience might imply better access to potential stakeholders for companies, it might also imply stakeholders that are more critical. Referring to the point of better information - actors have access to diverse search engines and social media platforms enabling access to global information. However, since individualized, nontransparent algorithms (cf. Hamilton et al. 2014) influence the results of an internet search as well as the news feeds on social media platforms, the access to information is determined according to one's interests and opinions. This leads to the problem of self-referentiality: the reproduction of own opinions and interests. These phenomena are worth mentioning based on their influence on human communication. However, analyzing those would go beyond the scope of this article. 
(cf. Rosa 2016: 24f., 198f., 281-298). When (unconsciously) aiming at positive feedback for complying with availability or checking if the last post led to reactions such as >Likes<; corporate members aim at feeling perceived by and connected to others (cf. ibid.: 159). However, these (resonance) signals are not sustainable and follow an acceleration logic - the more >Likes<, processed e-mails or praises, the better (cf. ibid.); these signals can function as digital social control influencing one's actions.

Following this logic, conditions at the workplace are changing. E.g., receiving praise for a fast reaction on an e-mail request functions as self-reinforcing social control (cf. Lamnek et al. 2012: 76). Through interactive expectation building (cf. Sydow et al. 2009: 700) and attempts to generate resonance experiences, other colleagues feel a slight pressure to act in that way as well.

If corporate members receive a work e-mail outside regular working hours or if they know that colleagues are e-mailing outside working hours, they perceive such driving forces and also comply with such a pattern (cf. Menz 2017: 22). At the same time, expectations of others adapt: more and more corporate members expect others to process messages and requests permanently or in general to be available permanently (cf. Urban/Ehlscheid 2016: 294). Approximately 88 percent of corporate members in Germany are also available for colleagues, superiors or customers outside regular working hours (cf. Bundesverband Informationswirtschaft, Telekommunikation und neue Medien 2011: 49).

In some cases, the company or the current project requests availability, i.e., corporate members cannot decide it (cf. Menz 2017: 15-20). In other cases, it is a sfree decision (cf. ibid.: 20-24). In this last case, corporate members often intend to offload themselves in order to avoid too much work during regular working hours.

The study of Menz (ibid.: 22) also confirms that unintended consequences in form of accelerated communication and higher availability expectations develop. This can potentially lead to the described impulse of accelerated communication and an implicit availability request. E.g., significant e-mail traffic already emerges on Sundays.

As soon as changing expectations lock-in, corporate members are required to be salways on<, which demands a permanent representation of one's professional role and norms. Certainly, the corporate member is still sfree to interrupt this permanent representation. E.g., some corporate members use the smartphone's flight mode when they have family time.

The study of Strobel (2013: 18) showed that the extent of perceived freedom is a condition for the positive effects of permanent availability. If the corporate member is able to say sno (e.g., flight mode) or is able to control the extent of work, the effects are more positive. In the ideal case, there is freedom to also ignore a request without expecting sanctions. ${ }^{12}$

12 If such freedom does not exist, permanent availability rather develops to an implicit expectation and action request (cf. Menz 2017: 22; Hassler et al. 2016: 13). 
However, this freedom has its limits where other corporate members or potential new corporate members are willing to be available permanently (social embeddedness). Since corporate members are competing with each other, they have to assert themselves. Having corporate members that are available permanently enables faster and more efficient work processes. This is highly desirable for companies. Thus, it is a competitive disadvantage if one is not complying (cf. Zuboff 1988: 351). Being ffree from a norm of permanent availability is combined with the question of whether the corporate member is able to afford it while facing competition through the labor market. Hence, possibilities to escape a (new) norm depend on one's conditions and one's socio-demographic background.

These developments are of a subtle nature, which is typical for social control. Even if availability is currently voluntary, it can subtly rigidify into a norm (based on accelerated communication and the implicit availability request) as explained above. It is this newly developing subtlety that changes the conditions for moral discernment. Those subtly changing conditions can be dimly recognized and hardly understood.

Zuboff (ibid.: 348) identified that with the rise of digital information, more objective data is accessible. However, managerial skills remained more or less traditional and limited their competence to deal with the overload of information.

If technology develops further and further while human competencies do not, problems of understanding influences of new communication technology prevail. Certainly, over the years, practice and academia has also developed further on the side of human competencies. However, there is still a need to upgrade human development to technological development, especially in management positions (cf. Sinn 2015).

\subsection{Indirect Communication: The Path to Secret Surveillance}

A specific peculiarity and challenge of digital communication is its indirect character; i.e., there is no face-to-face contact. ${ }^{13}$ With increasing indirect communication, it becomes more difficult for corporate members to process direct cues regarding the recipients' personality and emotions (cf. Rockmann/Northcraft 2008; Kezsbom 2000: 34). This is especially present if one is very active on social media or if one has to deal with different partners from abroad or simply if a company's communication mainly takes place via digital communication systems (cf. Zuboff 1988: 362-386). Since digital communication is more (cost-) efficient, this is often preferred.

Zuboff (ibid.: 370 ) presents a case where digital communication is described as a >combination of isolation and connectedness tation of a computer conferencing system in the daily operations of a company:

»Computer conferencing is a communications medium that offers an alternative to the constraints of geography and time associated with face-to-face meetings or

13 Verbal communication via telephone or the like is not part of this analysis. 
telephone conversations while avoiding the formality of written correspondence." (ibid: 364).

Corporate members explain that this form of communication leads to psychological security enabling more honest communication (ibid.: 370 ). This may also be related to the indirect character. In contrast to more direct communication, corporate members are subtly motivated by benefits like psychological security to use digital communication technologies.

However, this example also presents another digital social control: secret surveillance through panoptic power. Panoptic power can be understood as centralized power of managers using communication technology as tools of observation and control. ${ }^{14}$

The term ssecret already indicates that subtle influences continue to play a significant role. Again, problems like these have already been prevalent before the age of digital communication. Nonetheless, the subtlety has reached a new level based on the development of technology. Through digital communication technology, control mechanisms are hardly visible, or even completely invisible. Therefore, surveillance through other corporate members becomes easier to hide. On the other hand, every digital communication is transformed into a concrete presence through technological systems, meaning it can easily be made visible and traced back (cf. ibid.: 376, 381, 384).

Referring to the case of Zuboff (ibid.: 362-386), managers have exploited the involuntary display of the employees and have violated privacy and trust. Even if conversations were designated as >closed , the content was in fact open for unilateral screening (ibid.: 383f.). Indeed, management had new possibilities to optimize employees' performance and increase productivity based on such involuntary displays. As discussed above, the accounts of internal surveillance in companies is increasing (cf. Witte/Wendt 2013; MDR 2017).

The problem is, even if new laws have been passed to prevent such methods (cf. Bundesarbeitsgericht 2017), corporate members cannot know if that is the case or not. Approximately 46 percent of corporate members in Germany feel a higher degree of surveillance (cf. DGB 2016: 13). These new contingencies fundamentally challenge conditions of digital communication. According to the presented case of Zuboff (1988: 385): "Management has not been able to appreciate how the electronic network improved morale. The company hierarchy does not have a very good understanding of the social and emotional needs of people to communicate. They have become preoccupied with security, cost, and counterculture/ egalitarian issues."

14 Panopticism was originally developed by Foucault (1995) based on the Panopticon of Bentham (1791). The Bentham (1791) panopticon is a type of institutional building enabling that all members of the institution can be observed by one watchman without recognizing whether they are observed or not. Foucault (1995) used the Panopticon to develop the social theory of panopticism which explained the changing surveillanceand control mechanisms and resulting compliance requirements in the course of the $18^{\text {th }}$ century. 
It has been shown that digital communication gives rise to new (digital) social control $\left(\mathrm{H}_{1}\right)$. Based on its subtlety, digital social control makes it harder for corporate members to understand conditions of communication $\left(\mathrm{H}_{2}\right)$.

The following pages are devoted to theoretically reconstructing the resulting challenge for moral discernment.

\section{A New Challenge for Moral Discernment}

\subsection{Moral Discernment and the Practical Syllogism}

Moral discernment is a competence, which enables moral evaluation of actions, as well as the derivation of legitimate expectations. It concerns an integrated consideration of values (what does really matter?) and reality (what prevents us from acting accordingly?) in order to derive decisions (what is the right thing to do?) (cf. Suchanek 2015: 9f., 13f., 42, 152, 174).

This can be enabled by decisions according to the practical syllogism (ibid.: 4246). This syllogism is an ethical heuristic supporting the competence of moral discernment (cf. figure 2). Using this heuristic in order to conceptualize moral discernment intends to systematically exemplify that a weak understanding of conditions of communication diminishes moral discernment.

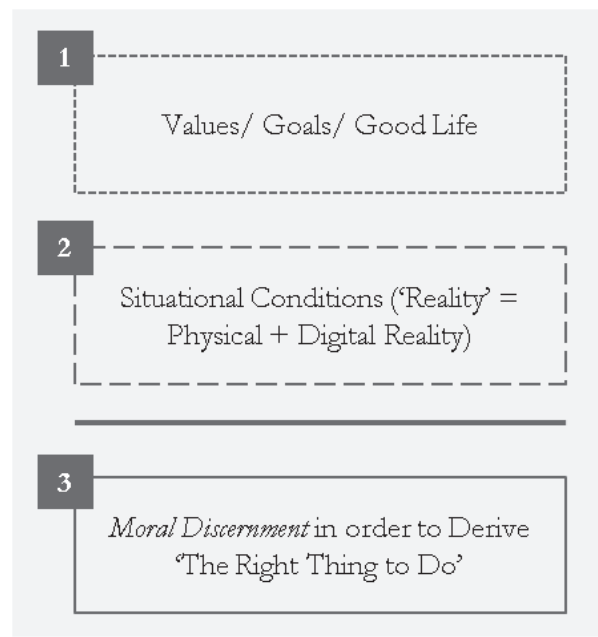

Figure 2: The Practical Syllogism (Source: Suchanek 2015: 44)

The following thoughts shed light on this ethical heuristic and make it more tangible. A fundamental question in ethics remains , What is the right thing to do? (compare to level 3 in figure 2 above). This question not only illuminates insights on what are reasonable actions or investments; but also on what one can expect. Answering this fundamental ethical question necessitates pre-classifications. Hence, preliminary questions have to be asked. 
Firstly, What does really matter in life? (see level 1). Typical answers are health, family, freedom, satisfaction or social acceptance. Generalizing this leads us to typical (moral) values, normative ideals or a good life. Secondly, If all this really matters to us, what encourages us and more importantly, what prevents us from acting accordingly?< (compare to level 2). This question addresses the situational conditions.

In ethics, this question is often given insufficient attention as the normative ideals and values are given priority. ${ }^{15}$ However, the moral value of moral discernment lies in exactly this nexus of level 1 and 2, which gives relevance and suitability for the everyday application of ethics.

As an example, freedom (level 1) does not imply doing whatever you want. Freedom lies in the recognition of one's own freedom with respect to the freedom of others (level 2). This implies the reflection of one's actions regarding the interests of others and one's own dependence on others. ${ }^{16}$ Humans become free if they are able to understand their embeddedness by their own self-reflection (cf. Durkheim 1984 [1922]). In other words, it is about a reciprocal recognition of the interests of and dependencies on others (social embeddedness).

This short excursus on freedom shows that level 1 (freedom) depends on level 2 (embeddedness) in order to derive ethical decisions for everyday use. If corporate members derive decisions by only addressing level 1 , it potentially leads to excessive moral demands. On the other hand, if corporate members derive decisions by only addressing level 2 , it potentially leads to immoral concepts.

The following two examples clarify the corresponding fallacies:

1. Normativistic Fallacy (deriving the right thing to do only from level 1: values):

It is comparably easy to be against permanent availability or secret surveillance because it might be against values like freedom or privacy (level 1) - so long as one is not confronted with the distinctive forces of a situational conflict, like an important project or pressure from colleagues (level 2).

2. Empiric Fallacy (deriving the right thing to do< only from level 2: conditions): Vice versa, it is also possible that corporate members who are highly integrated into the digitalized world know about the shortcomings or risks of these developments. However, they view these influences as immanent factor of the (digital) reality (level 2), whereby they are undermining essential values (level 1) that would guide their actions to sustainable cooperation, or simply to the >right decision<.

15 This might be reasonable if the problem at hand is focusing on the identification or justification of normative ideals (level 1) which is why the implementation aspect (level 2) becomes subordinate. However, as this ethical approach is about the integration of level 1 and level 2, the authors are abstaining from this focus on level 1.

16 This approach is discussed comprehensively by Hegel (1986 [1820]), Durkheim (1984 [1922]), Marx and Engels (1962 [1846]: 74) and Han (2016). 
Both views imply a reductionist view of decision-making. But, such developments are rarely black-or-white (cf. Badaracco 2016a; 2016b; Böldicke/Erfurt Sandhu 2017: 57). Rather, it is a question of reflecting potential fallacies: neither permanent availability nor new surveillance potential are fault-free developments empowering humans to infinite freedom of action, nor are they hostile developments which reduce humans to mere factors of production. The answer is usually in between.

With level 1 and level 2, the practical syllogism considers the discrepancy between values and reality, which is essential for critically evaluating the driving forces of digital communication (that means considering both, opportunities and risks). This approach is essential for developing a diagnostic capability for the impediments as well as conducive conditions (level 2) of a good life (level 1) and finally, for the >right $<$ decisions or investments (level 3).

This becomes problematic if newly developing conditions further complicate moral discernment according to the practical syllogism. In particular, the derivation of the right thing to do (level 3 ) is getting increasingly difficult due to the subtlety of digital social controls (level 2).

The next section is dedicated to applying the category of digital social control to the practical syllogism $\left(\mathrm{H}_{3}\right)$.

\subsection{The Practical Syllogism and Digital Social Control}

Social control regulates common agreements among social actors about what constitutes adequate attitudes and behavior (cf. O'Reilly 2008). The special nature of social control is its subtle character: corporate members do not feel heteronomous control. They even feel as if they have great freedom, although they are paradoxically conforming much more to corporate standards (ibid.: 88).

Social control is an ever-present and inevitable phenomenon which influences actions according to norms (cf. Singelnstein/Stolle 2012: 11). As such, norms influence expectations and thereby may function as an incentive for cooperation (cf. Park/Burgess 1921: 42; Park 1921: 20). These sorts of forces are an inherent element of every societal group: norms guide everyday actions and are necessary for viable forms of organization (cf. Ross 1896: 519; Jannowitz 1975: 82). However, due to their subtle nature, these forces can develop unconsciously. If these driving forces occur in combination with promising new opportunities, as it is within the digital age, subtly developing consequences become hard to recognize.

(Corporate) norms or standards are conceptualized as behavioral regularities, which are affirmed by sanctioning deviant behavior (cf. Popitz 1980) or by encouraging compliant behavior e.g., by positive feedback (cf. Coleman 1994 [1990]: 244).

An example for sanctions is social exclusion (e.g., none or negative reactions on a post that is deviating from corporate expectations). Social reactions in case of compliant behavior are praise (e.g., personal praise by one's superior for the fast reaction on an e-mail request) or rewards (e.g., a high amount of >Likes`) (cf. 
Lamnek et al. 2012: 76). These forms of social control forces are categorized as external social control.

Internal social control forces are based on the internalization of expectations. Regulatory mechanisms result in a bad conscience in case of deviant behavior (e.g., guilt feelings, regret or shame) and in positive self-confidence (e.g., pride or ease of mind) in case of expected behavior. Both forms are interdependent, (one can also feel guilty while at the same time being socially excluded due to one's post)..$^{17}$

Some social control forces are difficult to categorize clearly into one of these dimensions. Driving forces such as acceleration, the attempt to generate resonance experiences or indirect communication (cf. section 2) can be considered to be both external and internal social controls. Since corporate expectations and social control are mechanisms, which guide social behavior, they are a constitutive factor of every form of organization. Hence, the proposal to eliminate such forces or the like is not appropriate.

The figure below transfers the concept of the practical syllogism to the influences of digital social control. This illustrates the challenge posed to moral discernment.

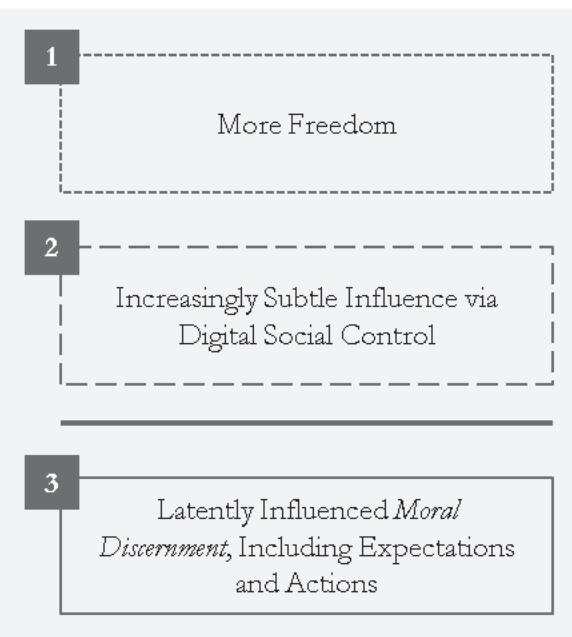

Figure 3: Practical Syllogism and Digital Social Control (Source: Own illustration based on Suchanek 2015: 44)

17 A noteworthy example for this is the termination of employment of a Porsche apprentice because of his Facebook post containing a call for violent behavior towards a refugee (cf. Munzinger/Anetzberger 2015). Consequences were the exclusion from the company as well as possibly regret for his actions. This shows the blurring separation of private and work life caused by digital communication as well as the norm of permanent availability, since the apprentice received consequences with regard to its professional role although, at that time, the representation of the professional role was not directly required. 
Freedom (1) is understood as the normative self-conception (meaning of a good life) of humans including their roles as corporate members (cf. Rosa 2016: 18, 40, 672; Crawford 2016: 35, 120f.).

According to level 2, corporate members must identify conducive or hindering conditions regarding this overarching goal. At this level, they are faced with the aforementioned problem of digital social controls. This challenges the competence of moral discernment: new conditions are hard to understand (level 2), expectations and actions are unconsciously adapted (level 3). This is mirrored in $\mathrm{H}_{3}$ : When a solid understanding of conditions of communication is lacking, strong moral discernment is impossible.

By this point at the latest, it is clear, that the challenge for moral discernment is caused by the weak digital literacy of corporate members. Part of digital literacy is a general understanding of possible processes that are latently taking place when communicating digitally (cf. Hamilton et al. 2014).

If corporate members are trained to develop digital literacy ${ }^{18}$, the path for improved moral discernment is facilitated. However, this is just the precondition. Therefore, training should consist of digital literacy in combination with moral discernment (cf. section 4.1).

If moral discernment is not trained within companies, a potential outcome is digital alienation $\left(\mathrm{H}_{4}\right)$. As such, the next section is devoted to theoretically reconstructing the new category of digital alienation.

\subsection{Digital Alienation Based on a Lack of Understanding}

Throughout this paper, it has been argued that digital social control has a subtle character: corporate members do not feel heteronomous control. The authors argue that, based on the developments examined thus far, a digital form of alienation develops. The starting point of these considerations is heteronomy as an inevitable condition of action in professional relationships.

Heteronomy is often understood as the opposite of freedom. It refers to a situation wherein a human's actions are mainly influenced indirectly by external conditions rather than directly by themselves. However, as explained in section 3.1, freedom is about the reciprocal recognition of the interests of and dependencies on others. According to this logic, heteronomy is not the opposite of freedom; rather freedom and heteronomy are interdependent states.

Heteronomous dependencies are indispensable and omnipresent, especially in professional relationships in times of division of labor. As it is an integral component of cooperation, heteronomy can lead to more productivity, efficiency or innovative products and services. Heteronomy is not a problem per se, but it can develop into a problem if it leads to alienation.

Especially in the industrial age, alienation was a job-related problem based on monotonous tasks and a lack of understanding the big picture of one's actions

18 It has to be noted that digital literacy should be trained on management- as well as on employee-level. This is necessary in order to enable an adequate understanding of new conditions of digital communication. 
and their causal relationships (cf. Marx/Engels 1962 [1846]: 34). In general, the problem emerges if humans are not able to understand conditions of actions, in which they are embedded (cf. Paul/Suchanek 1994: 3). This is often accompanied with a feeling of losing control ${ }^{19}$ (for more details see Paul/Suchanek 1994; May 1985: 54; Lankenau 1986: 71f.; Dahrendorf 1959: 78).

Since this article focuses on the problem of a weak understanding of newly developing conditions in digital communication, the authors constrain the analysis on the possible development of alienation based on a lack of understanding (there are also other causes, for instance factual dysfunctionalities or a missing sense of purpose for one's work). This is in line with Paul/Suchanek (1994: 1), who identify two central aspects of alienation (only those aspects which are relevant to $\mathrm{H}_{4}$ are presented):

1. Traditional conditions (of communication) lose overall validity (e.g., humanto-human communication becomes indirect, changes in conditions of privacy and surveillance of communication, cf. section 2.2).

2. Conditions (of communication) develop their own autonomy (e.g., in form of self-reinforcing mechanisms through acceleration and resonance experiences leading to permanent availability, cf. section 2.1).

Both aspects complicate the understanding of newly developing conditions. The problem of alienation is the circumstance that even though corporate actors might not understand their conditions, they have to comply with the corresponding requirements (cf. Weber 1988 [1920]: 37).

On this basis, digital alienation refers to corporate members' relation with newly developing conditions of digital communication. In particular, if digital literacy and moral discernment remain outdated, corporate members are becoming incrementally alienated from their conditions of communication including other persons and institutions. This is reflected in $\mathrm{H}_{4}$ : If moral discernment is not trained within companies, a potential outcome is digital alienation. One could say, while we are digitally connecting more and more, we are analogously becoming alienated from others.

This is well illustrated in the changes discussed above (cf. section 2): With indirect communication, corporate members perceive psychological security enabling them to communicate more honestly (cf. Zuboff 1988: 370). Obviously, it is less difficult to overcome oneself being honest. At the same time, corporate members are alienated from the communicated content, since the absence of face-to-face interaction makes the connection to the content (including the communication partner) more and more loose.

Further, if corporate members fear the risk of being controlled when communicating digitally (involuntary display), they might opt for anticipatory conformity (cf. ibid.: 381). This means, corporate members are stoning down< the character

19 Approximately 45 percent of corporate members in Germany feel powerless with regard to digital technology (DGB 2016: 15). 
of their communication. This sets the aspects of psychological security and honesty aside.

Obviously, while the intention of digital communication is to be connected with everybody, corporate members are paradoxically losing their (deeper social) connection; they become digitally alienated.

With regard to accelerated communication contexts, preset sentence components ('yours sincerely< or show are you?) are used to save time. At the same time, corporate members aim at resonance signals which follow an acceleration logic (cf. Rosa 2016: 159): They aim at receiving more and more signals of feeling connected and being perceived by others. Similar to the peculiarity of indirect communication, this also distances the corporate member from the communicated content : Communication is increasingly about the quantity rather than the quality of content.

The more corporate members become distanced from or indifferent toward the quality of communicated content, the better they can comply with the newly developing conditions of communication (cf. Rosa 2014 [2005]: 484). But, as long as corporate members rely on the familiarization or adequate understanding of working conditions, such a distance leads to (digital) alienation (ibid.: 484). Even though corporate members are embedded in these conditions of communication, they are losing the connection to it. It can be understood as a state of unrelated embeddedness (cf. Jaeggi 2016: 20-25).

Recapping, the risk of corporate members becoming digitally alienated from their conditions of communication prevails since (deeper social) experiences, which partially rely on interpersonal contacts, are fading into the background. This is an economic problem as this social dimension gives stability and trust (cf. Freud 2013 [1930]; Rockmann/Northcraft 2008), which is a crucial condition for functioning professional relationships (cf. Suchanek 2015). If moral discernment is not trained within companies, the risk of digital alienation prevails $\left(\mathrm{H}_{4}\right)$.

\section{Outlook}

\subsection{Institutionalization of Professional Training of Moral Discernment}

It has been shown that a main challenge of digital communication is that corporate members are subtly loosing track of the conditions and dependencies of this new communication form while the usage of communication technologies is increasing. Obviously, this discrepancy poses a challenge to moral discernment and can even lead to digital alienation.

In a work context, responsible behavior needs to be coordinated by stable structures and enabled by managers. This is necessary for enabling conducive role model behavior and >breathing room $>$ outside of professional roles.

The question arises: / Who is responsible?

The authors mainly focus recommendations on the meso-level (investments that companies can make). A problem could be that companies rather see these investments as opportunity costs which they prefer to avoid. As explained above, for a 
company it is also rather efficient if corporate members may be optimized through surveillance or if they process information permanently due to their constant availability (at least in the short- and medium-term).

However, some companies that reacted to the issues of digital communication received a push in their reputation (cf. Boewe/Schulten 2014: 18; Herrmann 2014; Federal Ministry of Labour and Social Affairs 2015). In order to transform the recommendations into investments, they need to be incentive-compatible. That means that there needs to be a clear value for the company (e.g., reputation advantages or less costs through fewer sick days). If this can be assured, companies can invest in responsible behavior in times of digital communication.

As indicated in section 3.2, digital literacy is a necessary precondition for moral discernment in today's corporate environment. Corporate members need to develop a better understanding of possible processes that are taking place whilst they are communicating digitally (e.g., invisible processes guiding the news feed on social media, accelerated communication or data storage on servers).

As such, the authors derive an integrated two-level approach for training managers' moral discernment in times of digital communication:

L1. Training of digital literacy by technology experts ${ }^{20}$

L2. Training of moral discernment by experts in business and economic ethics

As indicated, the two-level-training for managers should not be understood as two separated trainings: They need to be integrated, with both approaches trained together. E.g., when discussing data storage on servers (technology sector), the discussion needs to be extended towards cases of situational conflicts by applying ethical concepts like the practical syllogism (economic ethics sector). Questions like , What is the right thing to do if one gets asked to systematically check personal communication on a data server? or $>$ What is the right thing to do if one is perceiving an overload of digital information? need to be part of the discussions.

Within the digital age, managers are confronted with decisions such as these more and more often. It has to be noted that due to the different requirements and consequences for different positions, personalities and generations, as well as due to different forms of organizations, individual solutions have to be developed in a participatory approach, in conjunction with affected corporate members.

This can develop awareness on these newly developing and sensitive topics. This level of awareness is necessary in order to adequately deal with such forces at an early stage (e.g., not misusing digital social control in order to subtly force and exploit permanent availability or secret surveillance).

20 As indicated above, digital literacy should be trained on management- as well as on employee-level in order to prevent digital alienation. Training should be adapted with regard to competence, background knowledge and the position in the corporate hierarchy of the corporate members. However, the two-stage-training is only relevant for management. In that context, employees should be encouraged to consult their supervisors if they are not sure about the right thing to do. 
Indeed, there are also responsibilities on the micro-level (corporate members' way of digitally communicating) as well as on the macro-level (societal norms or governmental incentives). E.g., training of moral discernment can only be effective if managers are willing to be open for and invest in this competence. Further, government can also incentivize the institutionalization of such training.

\subsection{Interruption of Interdependence}

A reflected separation of private and work life is understood as interruption of interdependence ${ }^{21}$ (cf. Luhmann 2009: 240; 1991 [1984]: 52-55). This involves cutting off the connection between a corporate member's private roles and professional roles. This enables mental and technological detachment.

The ability to say 'no< was discussed above as a conducive condition. This can be seen as an interruption of interdependence; examples are activating a smartphone's flight mode, defining times in which a corporate memberis unavailable or shutting down the e-mail servers. However, this needs to be supported by corporate structures in which corporate members are embedded.

Interruption of interdependence can be seen as a form of self-commitment. Selfcommitment implies constraining oneself to a course of action that meets legitimate expectations (of oneself or of others) (cf. Suchanek 2011: 6). It means adhering to values and principles, especially in situational conflicts (cf. Suchanek 2015: 49-53, 85ff.).

Such principles can be privacy or the sright to recovery‘; while the situational conflict could for instance be the decision between being available or not. If corporate members are not able to say 'no< without risking competitive disadvantages, they get into the dilemma of deciding between loyalty to one's own values (health, privacy, etc.) or to the company's demands (efficiency, productivity).

It goes without saying that such a dilemma is neither conducive for the corporate member nor for the company, especially when aiming at long-term cooperation for mutual advantage, i.e., that the company invests in the corporate member's qualifications and the corporate member remains by the company and utilizes the qualifications accordingly. Hence, the loyalty to oneself and the loyalty to the company need to be enabled at the same time. However, if a corporate member assumes sanctions as the effect of not being available permanently, the corporate member is forced into the dilemma.

Such corporate conditions would also lead to corporate members being scaught in the orbit of interests and opinions of the professional roles of the corporate environment. This hinders their ability to understand the bigger picture since opinions are reproduced rather than reflected upon (cf. Böldicke/Erfurt Sandhu 2017). In other words, if interruption of interdependence is not possible, moral discernment, and correspondingly responsible decision-making, is constrained, even if digital literacy can be assumed.

21 An example would be activating a smartphone's flight mode, shutting down the e-mail servers of a company or deleting one's social media account. 
In conclusion, companies need to invest in regular training of digital literacy and moral discernment in order to prevent such situations as well as to reflect on them if they do occur, since they are unlikely to be prevented 100 percent of the time.

As indicated at the beginning of this article, the authors derive two needs for action:

1. Integration of rules of unavailability (new regulations for corporate members)

2. Institutionalization of professional training of moral discernment in order to promote responsible business behavior in times of digital communication (new two-level-training for managers)

While the theoretical focus remained on the second issue, the reader should now also understand the interdependence of both: The success of professional training depends on unavailability, since moral discernment depends on interruption of interdependence.

\section{References}

Badaracco, J. L. (2016a): How to Tackle Your Toughest Decisions, in: Harvard Business Review, September 2016 issue.

Badaracco, J. L. (2016b): Timeless Advice for Making a Hard Choice, in: Harvard Business Review.

Baumanns, M./Bidmon, C./Erfurt Sandhu, P./Leipprand, T./Triebel, O. M. (2015): Beyond Easy Answers. New Leadership Practice for the Digital Age, Berlin: LEAD: Mercator Capacity Building Center for Leadership \& Advocacy.

Bentham, J. (1791): Panopticon or the Inspection House: Containing the Idea of a New Principle of Construction, London: Verso.

Boewe, J./Schulten, J. (2014): Dienstplanung per Smartphone: Mobile Anwendungen zur Personaleinsatzplanung fordern Betriebsräte heraus, in: Magazin Mitbestimmung 12/2014, Hans-Böckler-Stiftung, 16-19. Link: https://www.boeckler.de/6299.htm?produkt=HBS-00 6277\&chunk = (zuletzt abgerufen am 22.08.2017).

Böldicke, E. M./Erfurt Sandhu, P. (2017): Ständig erreichbar: Die Entgrenzung von Mensch und Organisation, in: Zeitschrift für Unternehmensentwicklung und Change Management, Jg. 36/H. 4, 56-59.

Bundesarbeitsgericht (2017): Pressemitteilung Nr.31/17: Überwachung mittels Keylogger Verwertungsverbot. Link: http://juris.bundesarbeitsgericht.de/cgi-bin/rechtsprechung/docu ment.py?Gericht=bag\&Art=pm\&nr=19403 (zuletzt abgerufen am 21.08.2017).

Bundesverband Informationswirtschaft, Telekommunikation und neue Medien (2011): Netzgesellschaft: Eine repräsentative Untersuchung zur Mediennutzung und dem Informationsverhalten der Gesellschaft in Deutschland, Berlin: BITKOM.

Coleman, J. S. (1994 [1990]): Foundations of Social Theory, 1. Aufl., Cambridge, Mass.: Belknap Press of Harvard Univ. Press.

Crawford, M. B. (2016): Die Wiedergewinnung des Wirklichen: Eine Philosophie des Ichs im Zeitalter der Zerstreuung, Berlin: Ullstein.

Dabrendorf, R. (1959): Sozialstruktur des Betriebes, Wiesbaden: Gabler.

Derks, D./Brummelhuis, L. L. ten/Zecic, D./Bakker, A. B. (2012): Switching on and off ...: Does Smartphone Use Obstruct the Possibility to Engage in Recovery Activities? In: European Journal of Work and Organizational Psychology, Vol. 23/No. 1, 80-90. 
Derks, D./van Mierlo, H./Schmitz, E. B. (2014): A Diary Study on Work-Related Smartphone Use, Psychological Detachment and Exhaustion: Examining the Role of the Perceived Segmentation Norm, in: Journal of Occupational Health Psychology, Vol. 19/No. 1, 74-84.

DGB (2016): DGB-Index Gute Arbeit Der Report 2016: Wie die Beschäftigten die Arbeitsbedingungen in Deutschland beurteilen, Berlin: Institut DGB-Index Gute Arbeit.

Durkheim, E. (1984 [1922]): Erziehung, Moral und Gesellschaft: Vorlesung an der Sorbonne 1902/1903, 7. Aufl., Frankfurt a.M.: Suhrkamp.

Federal Ministry of Labour and Social Affairs (1995): Zeit- und ortsflexibles Arbeiten in Betrieben: Sammlung betrieblicher Gestaltungsbeispiele, BMAS: Berlin. Link: http://www. bmas.de/SharedDocs/Downloads/DE/PDF-Publikationen/a874.pdf?_blob=publicationFile $\& v=2$ (zuletzt abgerufen am 22.08.2017).

Foucault, M. (1995): Discipline and Punish: The Birth of the Prison, 2. Aufl., New York: Vintage Books.

Freud, S. (2013 [1930]): Das Unbehagen in der Kultur in: Das Unbehagen in der Kultur und andere kulturtheoretische Schriften, 3. Aufl., Frankfurt a.M.: Fischer.

Giersberg, G. (2014): Erfolg bei Evonik: E-Mail-freie Zone Freizeit, in: Frankfurter Allgemeine Zeitung. Link: http://www.faz.net/aktuell/beruf-chance/beruf/unternehmen-evonik-keine-emails-nach-feierabend-13256798.html (zuletzt abgerufen am 23.08.2017).

Hamilton, K./Karahalios, K./Sandvig, C./Eslami, M. (2014): A Path to Understanding the Effects of Algorithm Awareness, in: Jones, M./Palanque, P./Schmidt, A./Grossman, T. (Hrsg.): CHI '14 Extended Abstracts on Human Factors in Computing Systems, New York: ACM, 631-642.

Hampton, K. N. (2016): Persistent and Pervasive Community: New Communication Technologies and the Future of Community, in: American Behavioral Scientist, Vol. 60/No. 1, 101124.

Han, B.-C. (2016): Psychopolitik: Neoliberalismus und die neuen Machttechniken, 2. Aufl., Frankfurt a.M.: Fischer.

Hassler, M./Rau, R. (2016): Ständige Erreichbarkeit: Flexibilisierungsanforderung oder Flexibilisierungsmöglichkeit? in: Wirtschaftspsychologie, Jg. 18/H. 2, 25-34.

Hassler, M./Rau, R./Hupfeld, J./Paridon, H. (2016): Auswirkungen von ständiger Erreichbarkeit und Präventionsmöglichkeiten: Teil 2: Eine wissenschaftliche Untersuchung zu potentiellen Folgen für Erholung und Gesundheit und Gestaltungsvorschläge für Unternehmen, Dresden: Initiative Gesundheit und Arbeit (iga).

Hegel, G. W. F. (1986 [1820]): Grundlinien der Philosophie des Rechts oder Naturrecht und Staatswissenschaft im Grundrisse: Mit Hegels eigenhändigen Notizen und den mündlichen Zusätzen, Frankfurt a.M.: Suhrkamp.

Herrmann, C. (2014): Deutscher Betriebsräte-Preis 2014: Gold für BMW - Feierliche Preisverleihung in Bonn. Link: http://www.bund-verlag.de/zeitschriften/arbeitsrecht-im-betrieb/akt uelles/news/2014/10/gold-fuer-bmw-feierliche-preisverleihung-in-bonn.php (zuletzt abgerufen am 07.03.2017).

Hoffmann, D. (2014a): Keine E-Mails während der Freizeit: Continental: Tipps für Kommunikationspausen, in: Computerwoche von IDG. Link: https:/www.computerwoche.de/a/ke ine-e-mails-waehrend-der-freizeit,2556778,4 (zuletzt abgerufen am 23.08.2017).

Hoffmann, D. (2014b): Keine E-Mails während der Freizeit: Telekom: Definierbare Nichterreichbarkeit, in: Computerwoche von IDG. Link: https://www.computerwoche.de/a/keine-emails-waehrend-der-freizeit,2556778,5 (zuletzt abgerufen am 23.08.2017).

Jaeggi, R. (2016): Entfremdung: Zur Aktualität eines sozialphilosophischen Problems: mit einem neuen Nachwort, Berlin: Suhrkamp.

Jannowitz, M. (1975): Sociological Theory and Social Control, in: American Journal of Sociology, Vol. 81/No. 1, 82-108.

Kaufmann, M. (2014): Erreichbarkeit nach Dienstschluss: Deutsche Konzerne kämpfen gegen den Handy-Wahn, in: Spiegel Online. Link: http://www.spiegel.de/karriere/erreichbar-nach -dienstschluss-massnahmen-der-konzerne-a-954029.html (zuletzt abgerufen am 25.08.2017). 
Kezsbom, D. S. (2000): Creating Teamwork in Virtual Teams, in: Cost Engineering, Vol. 42/No. 10, 33-36.

Lamnek, S./Luedtke, J./Ottermann, R./Vogl, S. (2012): Tatort Familie: Häusliche Gewalt im gesellschaftlichen Kontext, 3. Aufl., Wiesbaden: Springer VS.

Lankenau, K. (1986): Entfremdung, in: Schäfers, B. (Hrsg.): Grundbegriffe der Soziologie, Leverkusen: Leske Verlag, 71-74.

Lubmann, N. (1991 [1984]): Soziale Systeme: Grundriß einer allgemeinen Theorie, 4. Aufl., Frankfurt a.M.: Suhrkamp.

Lubmann, N. (2009): Einführung in die Theorie der Gesellschaft: Transkription einer Vorlesung Luhmanns von 1992/93, 2. Aufl., Heidelberg: Auer.

Marx, K./Engels, F. (1962 [1846]): Die deutsche Ideologie, 3. Aufl., Berlin: Dietz Verlag.

May, H. (1985): Arbeitsteilung als Entfremdungssituation in der Industriegesellschaft von Emile Durkheim bis heute, 1. Aufl., Baden-Baden: Nomos Verlagsgesellschaft.

MDR (2017): Bundesarbeitsgericht: »Keylogger « zu Mitarbeiterüberwachung unzulässig, in: Mitteldeutscher Rundfunk. Link: http:/www.mdr.de/nachrichten/ratgeber/digitale-ueberw achung-von-arbeitnehmern-100.html (zuletzt abgerufen am 25.08.2017).

Menz, W. (2017): Erweiterte arbeitsbezogene Erreichbarkeit Ausprägungen, Belastungen, Handlungsstrategien: Ergebnisse einer qualitativen Beschäftigtenbefragung des Projekts MASTER - Management ständiger Erreichbarkeit, München: ISF München.

Mittelstadt, B. D./Allo, P./Taddeo, M./Wachter, S./Floridi, L. (2016): The Ethics of Algorithms: Mapping the Debate, in: Big Data \& Society, Vol. 3/No. 2, 1-21.

Munzinger, P./Anetzberger, M. (2015): Porsche entlässt Lehrling wegen Hetz-Kommentar, in: Süddeutsche Zeitung. Link: http://www.sueddeutsche.de/politik/oesterreich-porsche-entlae sst-lehrling-wegen-hetz-kommentar-1.2581466 (zuletzt abgerufen am 25.08.2017).

Nables, A. (2016): Die deutsche digitale Agenda und gute Arbeit, in: Schröder, L./Urban, H.-J. (Hrsg.): Gute Arbeit: Digitale Arbeitswelt - Trends und Anforderungen, Frankfurt a.M.: Bund-Verlag GmbH, 106-112.

O'Reilly, C. (2008): Corporations, Culture, and Commitment: Motivation and Social Control in Organizations, in: California Management Review, Vol. 50/No 2, 85-101.

Pangert, B./Pauls, N./Schlett, C. (2017): Maßnahmen zur gesunden Gestaltung ständiger Erreichbarkeit: Ergebnisse und Bewertung der MASTER-Workshops, Freiburg: Albert-Ludwigs-Universität Freiburg.

Park, R. E. (1921): The Social Organism and the Collective Mind, in: American Journal of Sociology, Vol. 27/No. 1, 1-21.

Park, R. E./Burgess, E. W. (1921): Introduction to the Science of Sociology, Chicago: The University of Chicago Press.

Paul, F./Suchanek, A. (1994): Entfremdung und Institutionen: Diskussionsbeiträge der wirtschaftswissenschaftlichen Fakultät Ingolstadt der Katholischen Universität Eichstätt, H. 44.

Popitz, H. (1980): Die normative Konstruktion von Gesellschaft, Tübingen: Mohr Siebeck.

Rockmann, K. W./Northcraft, G. B. (2008): To Be or Not to Be Trusted: The influence of media richness on defection and deception, in: Organizational Behavior and Human Decision Processes, Vol. 107/No. 2, 106-122.

Rosa, H. (2014 [2005]): Beschleunigung: Die Veränderung der Zeitstrukturen in der Moderne, 10. Aufl., Frankfurt a.M.: Suhrkamp.

Rosa, H. (2016): Resonanz: Eine Soziologie der Weltbeziehung, 2. Aufl., Berlin: Suhrkamp.

Ross, E. A. (1896): Social Control, in: American Journal of Sociology, Vol. 1/No. 5, 513-535.

Schmidt, E./Cohen, J. (2014): The New Digital Age: Reshaping the Future of People, Nations and Business, London: Murray.

Singelnstein, T./Stolle, P. (2012): Die Sicherheitsgesellschaft: Soziale Kontrolle im 21. Jahrhundert, 3. Aufl., Dordrecht: Springer.

Sinn, W. (2015): Digital-physische Transformation: Wie Unternehmen »digicale « Strategien erfolgreich umsetzen, in: Zeitschrift für Unternehmensentwicklung und Change Management, Jg. 34/H. 3, 11-13. 
Strobel, H. (2013): Auswirkungen von ständiger Erreichbarkeit und Präventionsmöglichkeiten: Teil 1: Überblick über den Stand der Wissenschaft und Empfehlungen für einen guten Umgang in der Praxis, Dresden: Initiative Gesundheit und Arbeit (iga).

Suchanek, A. (2011): Freiheit braucht Bindung, Lutherstadt Wittenberg: Wittenberg-Zentrum für Globale Ethik.

Suchanek, A. (2015): Unternehmensethik: In Vertrauen investieren, Tübingen: Mohr Siebeck.

Sydow, J./Schreyögg, G./Koch, J. (2009): ORGANIZATIONAL PATH DEPENDENCE: OPENING THE BLACK BOX, in: Academy of Management Review, Vol. 34/No. 4, 689709.

The Radicati Group (2016): Technology Market Research: Prognose zur Anzahl der täglich versendeten und empfangenen E-Mails weltweit von 2016 bis 2020 (in Milliarden). Link: http://de.statista.com/statistik/daten/studie/252278/umfrage/prognose-zur-zahl-der-taeglich -versendeter-e-mails-weltweit/ (zuletzt abgerufen am 16.09.2016).

United Internet (2017): Anzahl der jährlich versendeten E-Mails (ohne Spam) in Deutschland in den Jahren 2000 bis 2016 sowie eine Prognose für 2017 (in Milliarden). Link: https://de .statista.com/statistik/daten/studie/392576/umfrage/anzahl-der-versendeten-e-mails-in-deut schland-pro-jahr/ (zuletzt abgerufen am 15.08.2017).

Urban, H.-J./Ehlscheid, C. (2016): Gesundheit und Arbeitswelt - Perspektiven betrieblicher Präventionspolitik, in: Knieps, F./Pfaff, H. (Hrsg.): Gesundheit und Arbeit: Zahlen, Daten, Fakten mit Gastbeiträgen aus Wissenschaft, Politik und Praxis, Berlin: Medizinisch Wissenschaftliche Verlagsgesellschaft und BKK Dachverband e.V., 293-297.

Weber, M. (1988 [1920]): Gesammelte Aufsätze zur Religionssoziologie, 9. Aufl., Tübingen: Mohr Siebeck.

Witte, J./Wendt, L. (2013): Mobbing beim ADAC? Ex-Vorstand spricht von "Sumpf" beim ADAC in Niedersachsen, in: Norddeutscher Rundfunk. Link: http://www.ndr.de/der_ndr/ presse/mitteilungen/pressemeldungndr11929.html (zuletzt abgerufen am 25.08.2017).

Zuboff, S. (1988): In the Age of The Smart Machine: The Future of Work and Power, New York: Basic Books. 